\title{
Pengaruh Ketiadaan Inang terhadap Kapasitas Reproduksi dan Perilaku Parasitoid Apanteles taragamae Viereck (Hymenoptera: Braconidae)
}

\section{Effect of Host Deprivation toward Reproductive Capacity and Behavior of Apanteles taragamae Viereck (Hymenoptera: Braconidae)}

\author{
Fatimah Siddikah $^{1) *}$, Ihsan Nurkomar ${ }^{1)}$, \& Damayanti Buchori ${ }^{1)}$ \\ ${ }^{1)}$ Departemen Proteksi Tanaman, Fakultas Pertanian, Institut Pertanian Bogor \\ Jln. Meranti, Kampus IPB Dramaga, Bogor, Jawa Barat 16680 \\ *Penulis untuk korespondensi.E-mail: fatimah.siddikah@yahoo.com
}

Diterima 28 Februari 2018; diterima untuk diterbitkan 6 Juli 2018

\begin{abstract}
Apanteles taragamae (Hymenoptera: Braconidae) is a gregarious larval endoparasitoid of cucumber moth Diaphania indica (Lepidoptera: Crambidae). The success of biological control using parasitoids depends on reproductive behavior of adult female parasitoids, especially those related to the host availability that can affect oviposition behavior. The objectives of this research is to study the effect of host deprivation against reproductive capacity and searching and handling time behavior of A. taragamae. The study was conducted by depriving adult females of A. taragamae of host for 1, 2, 3, 4 days after emergence (virgin females with no oviposition experience) and experienced females. The parameters observed were the number of eggs laid on the first day after treatment, actual fecundity, ovary egg load, potential fecundity, longevity, searching and handling time of the first host after treatment. The results showed that host deprivation affect the number of eggs laid on the first day after treatment, ovary egg load, searching and handling time of host. Adult virgin females of A. taragamae without oviposition experience has more eggs laid on the first day after treatment, but has a slower searching and handling time for the first host after treatment than females with oviposition experience.
\end{abstract}

Keywords: Diaphania indica, oosorption, oviposition, parasitoid

\section{INTISARI}

Apanteles taragamae (Hymenoptera: Braconidae) merupakan parasitoid larva utama dari Diaphania indica (Lepidoptera: Crambidae) yang bersifat gregarius. Keberhasilan pengendalian hayati menggunakan parasitoid sangat tergantung pada perilaku reproduksi imago betina parasitoid, terutama yang berhubungan dengan ketersediaan inang yang dapat memengaruhi perilaku peletakan telur. Penelitian ini bertujuan untuk mempelajari pengaruh ketiadaan inang terhadap perilaku dan kapasitas reproduksi parasitoid A. taragamae. Penelitian dilakukan dengan cara memberikan perlakuan berupa ketiadaan inang selama 1, 2, 3, dan 4 hari setelah kemunculan $A$. taragamae menjadi imago (ketiadaan inang di depan) dan setelah $A$. taragamae mendapatkan inang terlebih dahulu (ketiadaan inang di belakang). Parameter yang diamati adalah jumlah telur yang diletakkan pada hari pertama setelah perlakuan, total telur yang diletakkan, sisa telur dalam ovari, potensi produksi telur, lama hidup imago A. taragamae, serta waktu pencarian dan penanganan inang pertama setelah ketiadaan inang. Hasil penelitian menunjukkan bahwa perlakuan ketiadaan inang memberikan pengaruh terhadap jumlah telur yang diletakkan pada hari pertama setelah perlakuan, jumlah telur yang tersisa dalam ovari, serta waktu pencarian dan penanganan inang pertama setelah perlakuan. Imago A taragamae pada perlakuan ketiadaan inang di depan meletakkan telur yang lebih banyak pada hari pertama setelah perlakuan, namun memerlukan waktu lebih lama dalam mencari dan menangani inang pertama dibandingkan imago A. taragamae pada perlakuan ketiadaan inang di belakang.

Kata kunci: Diaphania indica, oviposisi, parasitoid, penyerapan telur 


\section{PENDAHULUAN}

Diaphania indica Saunders merupakan hama minor pada tanaman Cucurbitaceae yang berpotensi menjadi hama primer, karena dapat menyebabkan kerusakan dalam jumlah besar pada tanaman mentimun (Fitriyana et al., 2015). Parasitoid Apanteles taragamae Viereck (Hymenoptera: Braconidae) merupakan endoparasitoid larva yang berpotensi mengendalikan D. indica di lapangan (Nixon, 1965). Nurkomar et al. (2017a) melaporkan bahwa A. taragamae memiliki keperidian potensial dengan tingkat parasitisasi yang tinggi serta kemampuan pencarian inang yang tinggi (Nurkomar et al., 2017b).

Salah satu faktor yang dapat memengaruhi keberhasilan pengendalian hayati dengan parasitoid adalah kapasitas reproduksi parasitoid. Menurut Godfray (1994), kapasitas reproduksi parasitoid dipengaruhi oleh kemampuan parasitoid dalam memproduksi telur. Bagi tipe parasitoid tertentu, ketersediaan inang menjadi faktor penting dalam produksi telur. Tersedianya inang secara terus-menerus dapat menstimulasi parasitoid untuk memproduksi telur, tetapi tidak tersedianya inang dalam beberapa waktu dapat menyebabkan terjadinya penyerapan kembali telur (Flanders, 1950; Jervis \& Kidd, 1986). Akbar (2012) dalam penelitiannya melaporkan berkurangnya ketersediaan inang dapat memengaruhi reproduksi parasitoid Snellenius manilae Ashmead (Hymenoptera: Braconidae), yaitu dapat menurunkan potensi telur yang diproduksi oleh parasitoid. Selain itu, Rohmani (2002) dalam penelitiannya melaporkan ketiadaan inang selama 3 jam terhadap parasitoid Trichogrammatoidea armigera Nagaraja (Hymenoptera: Trichogrammatoidea) dapat meningkatkan jumlah telur dalam ovari dan jumlah telur yang diletakkan pada hari pertama, tetapi menurun setelah 12 jam mengalami ketiadaan inang.

Sejauh ini, bagaimana pengaruh ketiadaan inang terhadap kapasitas reproduksi dan perilaku A. taragamae belum dipelajari. Tujuan dari penelitian adalah untuk mempelajari pengaruh ketiadaan inang terhadap kapasitas reproduksi dan perilaku parasitoid $A$. taragamae pada inang $D$. indica. Penelitian ini memberikan manfaat berupa informasi yang dapat digunakan dalam perbanyakan massal $A$. taragamae di laboratorium sebagai bagian dari kegiatan pengendalian hayati dengan parasitoid di masa yang akan datang.

\section{BAHAN DAN METODE}

\section{Pelaksanaan Penelitian}

Penelitian dilaksanakan di Laboratorium Pengendalian Hayati, Departemen Proteksi Tanaman, Fakultas Pertanian, IPB, dari bulan Maret sampai Desember 2016.

\section{Perlakuan Ketiadaan Inang}

Penelitian dilakukan dengan mengacu pada Akbar (2012) dengan modifikasi berupa penyesuaian jenis perlakuan ketiadaan inang yang disesuaikan dengan karakter biologi parasitoid A. taragamae. Parasitoid A. taragamae memiliki lama hidup reproduktif selama 4,90 hari (Nurkomar et al., 2017a), sehingga ditentukan lama ketiadaan inang untuk penelitian ini selama 4 hari.

Perlakuan ketiadaan inang dilakukan selama 1, 2, 3, 4 hari baik di depan (D) yaitu perlakuan ketiadaan inang yang diberikan sejak awal kemunculan A. taragamae menjadi imago, dan perlakuan ketiadaan inang di belakang (B) yaitu perlakuan ketiadaan inang yang diberikan setelah imago $A$. taragamae mendapatkan inang terlebih dahulu di awal kemunculannya menjadi imago. Kombinasi dari lama hari ketiadaan inang dan saat pemberian inang yang diujikan disajikan pada Tabel 1.

Tabel 1. Jenis perlakuan ketiadaan inang

\begin{tabular}{ccccccc}
\hline \multirow{2}{*}{ Perlakuan } & \multicolumn{7}{c}{ Umur parasitoid betina (hari) } \\
\cline { 2 - 7 } & 1 & 2 & 3 & 4 & 5 & 6 \\
\hline P1D & - & + & + & + & + & + \\
P2D & - & - & + & + & + & + \\
P3D & - & - & - & + & + & + \\
P4D & - & - & - & - & + & + \\
P1B & + & + & + & + & - & + \\
P2B & + & + & + & - & - & + \\
P3B & + & + & - & - & - & + \\
P4B & + & - & - & - & - & + \\
Kontrol & + & + & + & + & + & + \\
\hline
\end{tabular}

$\overline{\text { Keterangan: D: ketiadaan inang di depan; B: ketiadaan inang }}$ di belakang; -: tidak diberi inang; + : diberi inang

Masing-masing perlakuan dilakukan dengan cara memarasitkan satu imago betina parasitoid $A$. taragamae yang telah berkopulasi terhadap 10 larva D. indica berumur 3-4 hari selama 24 jam. Pemarasitan D. indica oleh A. taragamae dilakukan setiap hari dengan jumlah inang yang sama sampai 
A. taragamae mati. Masing-masing perlakuan diulang sebanyak 7 kali. Parameter yang diamati dalam penelitian ini yaitu:

a. Jumlah telur yang diletakkan pada hari pertama setelah ketiadaan inang. Jumlah telur dihitung dengan cara membedah tubuh inang yang sudah diparasitkan selama 24 jam di hari pertama imago betina $A$. taragamae mendapatkan inang setelah perlakuan. Pembedahan dilakukan di bawah mikroskop stereo. Pembedahan dilakukan dengan cara menarik ujung posterior larva dengan jarum mikro sehingga kutikula robek dan hemolimf serta telur parasitoid keluar. Jumlah telur dihitung dengan handcounter secara manual.

b. Total telur yang diletakkan imago betina $A$. taragamae. Jumlah telur yang diletakkan oleh imago betina $A$. taragamae sampai mati.

c. Potensi produksi telur. Potensi produksi telur (keperidian potensial/potential fecundity) merupakan kemampuan maksimum parasitoid betina menghasilkan telur selama hidupnya, yang meliputi jumlah telur yang diletakkan dalam inang dan jumlah telur yang tersisa dalam ovari (Handayani et al., 2004).

d. Lama hidup imago betina $A$. taragamae, dan

e. Perilaku $A$. taragamae yang mencakup waktu dalam mencari inang (searching time) serta waktu untuk menangani inang (handling time) ketika pertama kali imago A. taragamae mendapatkan inang setelah perlakuan ketiadaan inang.

\section{Analisis Data}

Data yang diperoleh dianalisis ragam (One Way ANOVA) dan perbandingan nilai tengah dianalisis dengan uji Duncan pada taraf nyata 5\%. Analisis data dilakukan dengan menggunakan Statistic Analytical Software (SAS) versi 9.1.

\section{HASIL DAN PEMBAHASAN}

Pengaruh Ketiadaan Inang terhadap Jumlah Telur yang Diletakkan pada Hari Pertama setelah Ketiadaan Inang

Hasil penelitian menunjukkan bahwa perlakuan ketiadaan inang memberikan pengaruh terhadap jumlah telur yang diletakkan di hari pertama setelah perlakuan $(\mathrm{P}=0,02 ; \mathrm{F}=2,38)$. Tidak ada perbedaan jumlah telur yang diletakkan $A$. taragamae setelah mengalami ketiadaan inang selama 1 hari baik pada perlakuan ketiadaan inang di depan maupun di belakang. Begitupun pada perlakuan ketiadaan inang selama 4 hari. A. taragamae meletakkan telur paling banyak setelah mengalami ketiadaan inang di depan selama dua hari (Gambar 1).

Parasitoid A. taragamae adalah parasitoid prosinovigenik (Nurkomar et al., 2017a), yaitu parasitoid yang memiliki sejumlah telur yang telah matang pada saat kemunculannya menjadi imago dan jumlahnya terus mengalami peningkatan (Quicke, 1997). Peningkatan jumlah telur tersebut menunjukkan bahwa parasitoid $A$. taragamae dapat memproduksi telur kembali selama sisa hidupnya. Berbeda halnya dengan parasitoid proovigenik yang tidak dapat memproduksi telur terus menerus selama hidupnya (Godfray, 1994). Hal tersebut didukung dengan adanya peningkatan jumlah telur bagi imago yang mengalami ketiadaan inang selama 2 hari di depan sebagai akumulasi telur dari respons ketiadaan inang tersebut. Sedangkan, penurunan jumlah telur setelah imago betina $A$. taragamae tidak mendapatkan inang selama 3 hari di depan menunjukkan adanya penyerapan kembali telur sebagai respon yang dikenal dengan fenomena oosorption (Quicke, 1997).

Peningkatan lama hari ketiadaan inang dapat meningkatkan jumlah telur yang diletakkan pada

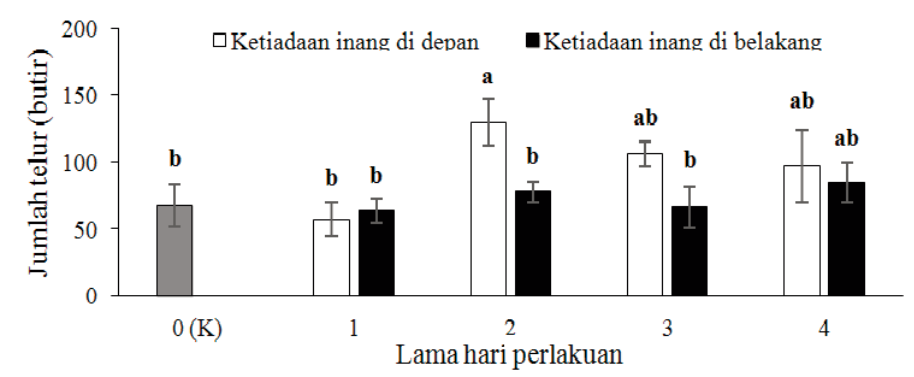

Gambar 1. Jumlah telur yang diletakkan betina Apanteles taragamae pada hari pertama setelah perlakuan ketiadaan inang; setiap bar yang disertai huruf berbeda menunjukkan nilai yang berbeda nyata berdasar uji Duncan pada taraf nyata $5 \%$ 
hari pertama setelah perlakuan meski hanya pada perlakuan ketiadaan inang sampai 2 hari. Peningkatan jumlah telur yang diletakkan diduga disebabkan oleh terjadinya penumpukan telur dalam ovari imago betina. Handayani et al. (2004) mengatakan bahwa parasitoid akan memaksimumkan peletakan telur pada saat pertama kali parasitoid mendapatkan inang. Jumlah telur yang diletakkan di hari pertama setelah perlakuan pada ketiadaan inang di depan memiliki jumlah telur yang lebih tinggi dibandingkan dengan imago betina A. taragamae pada perlakuan ketiadaan inang di belakang. Hal tersebut menunjukkan bahwa pengalaman bertemu inang ternyata tidak meningkatkan jumlah telur yang diletakkan imago $A$. taragamae pada hari pertama setelah perlakuan. Hal ini berbeda dengan hasil penelitian Drost dan Carde (1992) yang melaporkan bahwa pemaparan awal inang terhadap parasitoid sebelum ketiadaan inang dapat meningkatkan produsksi telur viabel yang lebih tinggi dibandingkan dengan parasitoid tanpa pemaparan awal inang.

\section{Pengaruh Ketiadaan Inang terhadap Potensi Produksi Telur dan Lama Hidup A. taragamae}

Perlakuan ketiadaan inang memberikan pengaruh terhadap telur yang tersisa di dalam ovari imago $A$. taragamae $(\mathrm{P}=0,03 ; \mathrm{F}=2,31)$. Apanteles taragamae yang mengalami ketiadaan inang di depan memiliki jumlah sisa telur dalam ovari yang relatif sama. Namun, A. taragamae yang mengalami ketiadaan inang di belakang hanya memiliki jumlah sisa telur dalam ovari yang relatif sama setelah tiga hari tidak mendapatkan inang. Jumlah sisa telur dalam ovari meningkat setelah 4 hari tidak mendapat inang di belakang (Tabel 2). Imago A. taragamae pada perlakuan ketiadaan selama 4 hari di belakang memiliki jumlah telur tersisa dalam ovari yang lebih banyak dibandingkan perlakuan ketiadan inang di depan.
Sisa telur dalam ovari imago betina $A$. taragamae pada perlakuan ketiadaan inang di belakang yang lebih banyak dibandingkan dengan perlakuan ketiadaan inang di depan, terkait dengan jumlah telur yang diletakkan oleh imago. Semakin tinggi jumlah telur yang diletakkan imago maka semakin sedikit jumlah telur yang tersisa dalam ovari imago.

Perlakuan ketiadaan inang memberikan pengaruh terhadap total telur yang diletakkan (keperidian nyata) imago $A$. taragamae $(\mathrm{P}=0,05 ; \mathrm{F}=2,04)$. Telur yang diletakkan pada perlakuan $\mathrm{P} 1 \mathrm{D}$ lebih banyak dibandingkan pada perlakuan P4D, P3B, P4B, tapi tidak berbeda nyata dibanding perlakuan lainnya (Tabel 2). Hal ini menunjukkan bahwa A. taragamae yang mengalami ketiadaan inang selama satu hari di depan, mampu meletakkan telur lebih banyak dibanding perlakuan lainnya.

Adanya perbedaan jumlah telur yang diletakkan pada setiap perlakuan diduga karena adanya proses penyerapan kembali telur sebagai respon perlakuan ketiadaan inang (Gordh et al., 1999). Menurut Jervis dan Kidd (1986), penyerapan kembali telur (oosorption) adalah mekanisme yang dilakukan imago betina untuk mendaur ulang nutrisi yang tersimpan dalam telur ketika kekurangan makanan dan inang. Penyerapan kembali telur dilakukan imago betina untuk mempertahankan pasokan telur yang telah matang ketika inang tidak tersedia, agar imago betina parasitoid dapat melanjutkan kembali oviposisi ketika inang sudah tersedia kembali (Rivero-Lynch \& Godfray 1997). Namun demikian, perlakuan ketiadaan inang tidak memberikan pengaruh terhadap potensi produksi telur/total telur (keperidian potensial) imago $A$. taragamae $(\mathrm{P}=0,2035 ; \mathrm{F}=1,43)$.

Lama ketiadaan inang juga tidak berpengaruh terhadap lama hidup imago A. taragamae $(\mathrm{P}=0,9152$; $\mathrm{F}=0,40)$. Hal tersebut terjadi baik pada perlakuan

Tabel 2. Pengaruh ketiadaan inang terhadap keperidian dan lama hidup imago betina Apanteles taragamae

\begin{tabular}{ccrrr}
\hline Perlakuan & Telur yang diletakkan $\pm \mathrm{SD}$ & Sisa telur $\pm \mathrm{SD}$ & Potensi produksi telur \pm SD & Lama hidup \pm SD \\
\hline Kontrol & $513,57 \pm 152,33 \mathrm{ab}$ & $101,86 \pm 65,12 \mathrm{~b}$ & $615,43 \pm 174,17 \mathrm{a}$ & $8,00 \pm 2,83 \mathrm{a}$ \\
P1D & $556,00 \pm 224,70 \mathrm{a}$ & $81,86 \pm 52,09 \mathrm{~b}$ & $637,86 \pm 242,53 \mathrm{a}$ & $8,29 \pm 1,89 \mathrm{a}$ \\
P2D & $486,29 \pm 270,52 \mathrm{abc}$ & $103,71 \pm 113,66 \mathrm{~b}$ & $590,00 \pm 237,63 \mathrm{a}$ & $9,00 \pm 3,21 \mathrm{a}$ \\
P3D & $398,00 \pm 153,70 \mathrm{abc}$ & $103,00 \pm 47,04 \mathrm{~b}$ & $501,00 \pm 142,62 \mathrm{a}$ & $8,71 \pm 2,81 \mathrm{a}$ \\
P4D & $326,14 \pm 215,36 \mathrm{bc}$ & $104,57 \pm 38,40 \mathrm{~b}$ & $430,71 \pm 196,77 \mathrm{a}$ & $10,00 \pm 2,89 \mathrm{a}$ \\
P1B & $403,43 \pm 97,87 \mathrm{abc}$ & $183,00 \pm 82,41 \mathrm{ab}$ & $586,43 \pm 93,52 \mathrm{a}$ & $8,29 \pm 2,69 \mathrm{a}$ \\
P2B & $434,29 \pm 111,10 \mathrm{abc}$ & $177,29 \pm 107,40 \mathrm{ab}$ & $611,57 \pm 138,46 \mathrm{a}$ & $8,86 \pm 2,34 \mathrm{a}$ \\
P3B & $317,29 \pm 86,46 \mathrm{bc}$ & $137,29 \pm 85,92 \mathrm{ab}$ & $454,57 \pm 107,87 \mathrm{a}$ & $9,43 \pm 2,70 \mathrm{a}$ \\
P4B & $280,14 \pm 167,12 \mathrm{c}$ & $226,57 \pm 128,46 \mathrm{a}$ & $506,71 \pm 99,39 \mathrm{a}$ & $9,57 \pm 3,41 \mathrm{a}$ \\
\hline
\end{tabular}

Keterangan: Nilai rata-rata yang diikuti huruf berbeda dalam satu baris berbeda secara signifikan berdasarkan uji Duncan pada taraf nyata $5 \%$. 
lama ketiadaan inang di depan maupun ketiadaan inang di belakang (Tabel 2). Fleury dan Bouletreau (1993) juga melaporkan ketersediaan inang tidak memberikan pengaruh yang signifikan terhadap lama hidup Trichogramma brassicae Bezdenko (Hymenoptera: Trichogrammatidae) jika madu sebagai makanan masih tersedia. Penelitian lain melaporkan bahwa perlakuan ketiadaan inang menyebabkan imago betina parasitoid menyimpan energi yang seharusnya digunakan untuk melakukan oviposisi sehingga umur imago betina menjadi lebih lama. Selain itu, nutrisi yang dihasilkan dari proses penyerapan telur digunakan sebagai sumber energi untuk hidup. Pemberian inang secara terus-menerus menyebabkan imago betina parasitoid terus melakukan oviposisi dan memproduksi telur sepanjang hidupnya. Oviposisi dan produksi telur yang terus-menerus membutuhkan energi yang dapat memperpendek lama hidup imago parasitoid (Quicke, 1997).

\section{Pengaruh Ketiadaan Inang terhadap Perilaku A. taragamae}

Ketiadaan inang berpengaruh terhadap waktu yang dibutuhkan $A$. taragamae dalam mencari inang pertama setelah perlakuan $(\mathrm{P}=0,0021 ; \mathrm{F}=4,23)$. Hasil penelitian menunjukkan bahwa waktu yang diperlukan A. taragamae dalam mencari inang pertama menjadi lebih lambat setelah $A$. taragamae mengalami ketiadaan inang di depan selama satu hari. Tidak ada perbedaan waktu yang diperlukan oleh $A$. taragamae dalam mencari inang pertama pada perlakuan ketiadaan inang lainnya (Gambar 2).

Secara umum, perlakuan ketiadaan inang menyebabkan A. taragamae memerlukan waktu lebih lama dalam mencari inang pertama. Puspaningtyas (2017) melaporkan bahwa pada kondisi inang tersedia, $A$. taragamae mampu mencari inang selama 39 detik. Penemuan inang pertama sering kali memerlukan waktu lebih lama karena adanya proses pengenalan habitat inang oleh imago parasitoid. Pengalaman yang dimiliki imago dalam mencari inang pertama biasanya akan dijadikan acuan dalam mencari inang selanjutnya (Vet et al., 1995). Hal ini dapat dilihat pada perlakuan ketidaan inang selama satu hari di belakang di mana A. taragamae lebih cepat dalam mencari inang pertama dibandingkan $A$. taragamae yang mengalami ketiadaan inang selama satu hari di depan.

Ketiadaan inang juga berpengaruh terhadap waktu yang diperlukan $A$. taragamae dalam menangani inang pertama setelah perlakuan $(\mathrm{P}=0,0220 ; \mathrm{F}=2,79)$. Ketiadaan inang selama satu atau empat hari di belakang membuat $A$. taragamae lebih cepat menangani inang pertama dibanding apabila $A$. taragamae mengalami ketiadaan inang selama satu hari di depan, tetapi tidak berbeda nyata dibanding lama ketiadaan inang lainnya (Gambar 3).

Perlakuan ketiadaan inang juga menyebabkan $A$. taragamae memerlukan waktu lebih lama dalam menangani inang pertama. Pada kondisi inang tersedia, A. taragamae menangani inang selama 17 detik (Puspaningtyas, 2017). Sama halnya dengan perilaku pencarian inang bahwa pengalaman menangani inang sebelumnya memberikan pengaruh dalam menangani inang selanjutnya seperti pada perlakuan ketidaan inang selama satu dan empat hari di belakang di mana $A$. taragamae lebih cepat dalam menangani inang pertama dibandingkan $A$. taragamae yang mengalami ketiadaan inang selama satu dan empat hari di depan. Drost dan Carde (1992) mengatakan bahwa adanya pengalaman dalam menangani inang dapat mendorong perilaku reproduksi imago parasitoid menjadi lebih aktif, serta memiliki penerimaan inang dan produksi telur viabel yang lebih tinggi dibandingkan parasitoid tanpa pengalaman bertemu inang sebelumnya. Pengalaman tersebut mempermudah parasitoid dalam menemukan inang yang cocok untuk oviposisi selanjutnya.

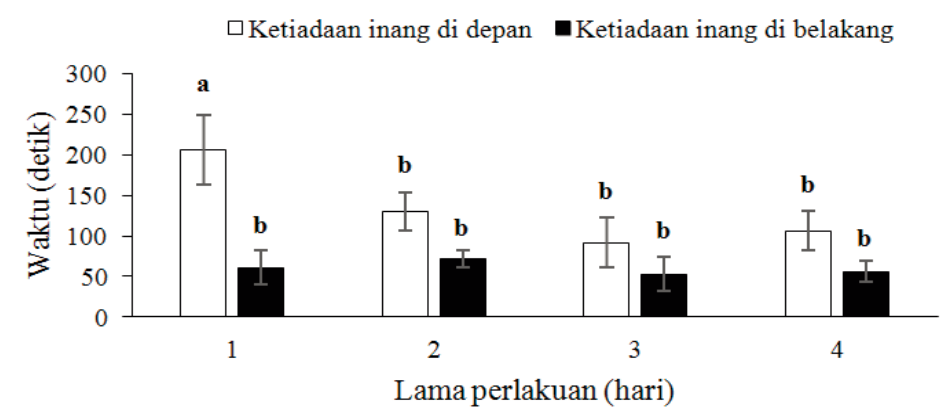

Gambar 2. Waktu pencarian inang pertama setelah perlakuan ketiadaan inang oleh Apanteles taragamae; setiap bar yang disertai huruf berbeda menunjukkan nilai yang berbeda nyata berdasar uji Duncan pada taraf nyata 5\% 


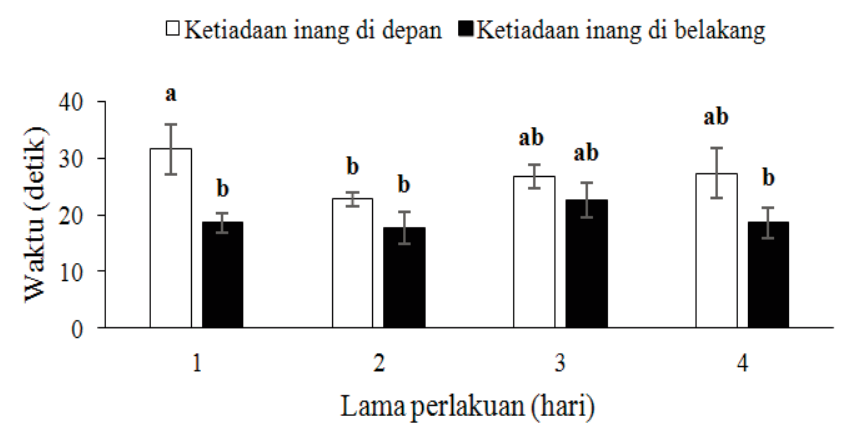

Gambar 3. Waktu penanganan inang pertama setelah perlakuan ketiadaan inang oleh Apanteles taragamae; setiap bar yang disertai huruf berbeda menunjukkan nilai yang berbeda nyata berdasar uji Duncan pada taraf nyata 5\%

Implikasi dari penelitian ini adalah pemarasitan A. taragamae dalam perbanyakan massal di laboratorium dapat dilakukan dengan menggunakan $A$. taragamae yang telah mengalami ketiadaan inang selama satu sampai dua hari di belakang. A. taragamae tersebut memiliki potensi jumlah telur yang diletakkan dalam jumlah tinggi, serta mampu mencari dan menangani inang lebih cepat.

\section{KESIMPULAN}

Lama ketiadaan inang memberikan pengaruh terhadap kapasitas reproduksi A. taragamae seperti jumlah telur yang diletakkan hari pertama dan sisa telur dalam ovari. Jumlah telur yang diletakkan pada hari pertama paling banyak diletakkan oleh $A$. taragamae yang mengalami ketiadaan inang di depan selama dua hari. Sedangkan, sisa telur di ovari paling banyak ditemukan pada $A$. taragamae yang mengalami ketiadaan inang di belakang selama empat hari.

Lama ketiadaan inang juga memberikan pengaruh terhadap perilaku pencarian dan penanganan inang. Apanteles taragamae menjadi lebih lambat dalam mencari inang setelah mengalami ketiadaan inang selama satu hari di depan, tetapi lebih cepat dalam menangani inang setelah mengalami ketiadaan inang selama satu atau empat hari di belakang.

\section{DAFTAR PUSTAKA}

Akbar, M.E. \& D. Buchori. 2012. Pengaruh Lama Ketiadaan Inang terhadap Kapasitas Reproduksi Parasitoid Snellenius manilae Ashmead (Hymenoptera: Braconidae). Jurnal Entomologi Indonesia 9: 14-22.
Drost, Y.C. \& R.T. Carde. 1992. Influence of Host Deprivation on Egg Load and Oviposition Behaviour of Brachymeria intermedia, a Parasitoid of Gypsy Moth. Physiological Entomology 17: 230-234.

Fitriyana, I., D. Buchori, A. Nurmansyah, R. Ubaidillah, \& A. Rizali. 2015. Statistik Demografi Diaphania indica (Saunders) (Lepidoptera: Crambidae). Jurnal Hama dan Penyakit Tumbuhan Tropika 15: 105-113.

Flanders, S.E. 1950. Regulation of Ovulation and egg disposal in the Parasitic Hymenoptera. Canadian Entomologist 82: 134-140.

Fleury, F. \& M. Bouletreau. 1993. Effects of Temporary Host Deprivation on the Reproductive Potential of Trichogramma brassicae. Entomologia Experimentalis et Applicata 68: 203-210.

Godfray, H.C.J. 1994. Parasitoid Behavioral and Evolutionary. Princeton University Press, New Jersey. $473 \mathrm{p}$.

Gordh, G., E.F. Legner, \& L.E. Caltagirone. 1999. Biology of Parasitic Hymenoptera, p. 255-381. In T. Bellows \& T.W. Fisher (eds), Handbook of Biological Control. California Academic Press, California.

Handayani, R.S., D. Buchori, \& D. Prijono. 2004. Pengaruh Pakan dan Inang terhadap Lama Hidup dan Produksi Telur Trichogramma pretiosum Riley (Hymenoptera: Trichogrammatidae), hlm: 45-60. Dalam M. Arifin, E. Karmawati, I.W. Laba, I.W. Winasa, Pudjianto, Dadang, T. Santoso, U. Kusumawati, D. Koswanudin, \& Mulyawan, (ed.), Seminar Nasional Entomologi dalam Perubahan Lingkungan dan Sosial. Bogor, Indonesia. Institut Pertanian Bogor, Bogor, 5 Oktober 2004. 
Jervis, M.A. \& N.A.C Kidd. 1986. Host-feeding Strategies in Hymenopteran Parasitoids. Biological Reviews 61: 395-434.

Nixon, G.E.J. 1965. A Reclassification of the Tribe Microgasterini (Hymenoptera: Braconidae). Bulletin of the British Museum (Natural History) Entomology Supplement 2: 1-284.

Nurkomar, I., N. Novianti, Pudjianto, S. Manuwoto, \& D. Buchori. 2017a. Biology and Fitness Characteristics of Apanteles taragamae Viereck (Hymenoptera: Braconidae). Journal of Entomology 14: $128-135$.

Nurkomar I., D. Buchori, D. Taylor, \& Y. Kainoh. 2017b. Innate Olfactory Responses of Female and Male Parasitoid Apanteles taragamae Viereck (Hymenoptera: Braconidae) toward Host Plant Infested by the Cucumber Moth Diaphania indica Saunders (Lepidoptera: Crambidae). Biocontrol Science and Technology 27: 1-10.
Puspaningtyas, N.N. 2015. Biologi dan Perilaku Apanteles taragamae Viereck. (Hymenoptera: Braconidae), Parasitoid Larva Diaphania indica Saunders. (Lepidoptera: Crambidae). Skripsi. Institut Pertanian Bogor, Bogor. 43 hlm.

Quicke, D.L.J. 1997. Parasitic Wasps. Chapman \& Hall, London. 470 p.

Rivero-Lynch, A.P. \& H.C.J. Godfray. 1997. The Dynamics of Egg Production, Oviposition and Resorption in a Parasitoid Wasp. Functional Ecology 11: 184-188.

Rohmani, A. 2002. Pengaruh Ketiadaan Inang terhadap Tanggap Reproduksi Trichogrammatoidea armigera Nagaraja dan Trichogramma japonicum Ashmed (Hymenoptera: Trichogrammatidae) dan Implikasinya terhadap Penerimaan Inang. Skripsi. Institut Pertanian Bogor, Bogor. 46 hlm.

Vet L.E.M, W. Lewis, \& R. Cardé. 1995. Parasitoid Foraging and Learning, p. 65-101. In W.J. Bell \& R.T. Cardé (eds), Chemical Ecology of Insects. Second Edition. Chapman \& Hall, New York. 